\title{
The Influence of Principal's Supervision and Participation of Committee on the Primary School's Performance
}

\author{
Karso $^{1}$, Muhammad Kristiawan ${ }^{2}$, Yessi Fitriani ${ }^{3}$ \\ ${ }^{1}$ SD Negeri 3 Pulau Rimau, ${ }^{2}$ Universitas Bengkulu, ${ }^{3}$ Universitas PGRI Palembang \\ * e-mail: karsoguru71@gmail.com
}

\begin{abstract}
This paper aimed at determining the principal's supervision and school committee participation on the primary school's performance in Pulau Rimau, Indonesia. The sample of this research is 40 elementary school teachers. Data were collected using questionnaire and documentation. Data were analyzed using the SPSS program. The results showed 1) there was positive influence of principal's supervision on the primary school's performance; 2) there was positive influence of school committee participation on the primary school's performance; 3) there was positive influence of principal's supervision and school committee participation together on the primary school's performance in Pulau Rimau, Indonesia. This paper contributed to principal on improving supervision and committee on participation in order to have very good primary school's performance. Since the school wishes to have good performance they should have good principal's supervision and committee's participation.
\end{abstract}

Keywords: Principal's Supervision; School's Committee; School's Performance; High Quality Education.

\section{INTRODUCTION}

Improving the quality of education is an inseparable part of developing human resources. These efforts must be carried out in a planned, directed and intensive manner to prepare the nation enter the era of globalization which is full of competition (Apriana et al., 2019; Sarina et al., 2019; Tobari et al., 2018; Wandasari et al., 2019). The quality of education is directed by the Law on the National Education System Number 20 of 2003, the development of students' potential to become human beings who believe and fear God Almighty, noble, healthy, knowledgeable, competent, creative, independent, and become citizens democratic and responsible country. Quality education is believed to be the right way to improve the quality of human resources (Irmayani et al., 2018). However, education in Indonesia has not been able to lead to quality improvement and it is still focused on quantity alone (Andriani et al., 2018). Where (Andriani et al., 2018) state that the quality of education in developing countries at Asia Pacific, Indonesia is ranked 10 out of 14 countries and for the quality of the teachers are in the last rank and the main factors that greatly affect the teachers performance is transformational leadership of principal related to supervision (Renata et al., 2018).

A good principal should have a clear vision of institutional conceptual abilities, and have skills and arts in the relationship between humans, mastering technical and substantive aspects, have a spirit of progress, service and character that is accepted by the community (Mulyasa, 2004). Principal's leadership pattern will be very influential even very determine the progress of the school. The principal as a leader must be able to motivate his subordinates, because the success of leader in moving people to achieve goals is very dependent on the authority they have. The new management paradigm of education gives broad authority to principals in planning, organizing, implementing, supervising and controlling education in schools. (Mulyasa, 
2004) said that professional school principals in the new paradigm of education management will have a positive impact and a fairly fundamental change in the renewal of the educational system in schools (Irwan Fathurrochman et al., 2019).

According to Ministry of Education Number 10 of 2010 the supervision carried out in the process of improving elementary school performance is divided into 3 categories 1) normative; 2) adaptive; 3 ) productive. In the process, there are some teachers who teach regularly need to be coached through the supervision of the principal and work closely with the school committee (parents of student) so that the results achieved by the primary school performance can be improved for the progress of the school such many teacher's expertise is inadequate, infrastructure and facilities are inadequate, teaching hours are not optimal. Whereas the school committee has the role and function as 1) advisory agency in determining and implementing educational policies; 2) supporting financial, thought and energy in the administration; 3 ) controlling the framework of transparency and accountability in the delivery of education; 4) mediator between the government and the community (Ministry of Education Number 10 of 2010).

The description above means the supervision of the principal is very important in determining the success or failure of the school in carrying out its duties as a school leader to educate the national life and develop the whole person. School performance is what school does relevant with National Standard of Education where it belongs to Government's Regulation of Indonesia Number 32 of 2013. Good or bad a school is more determined by the professional abilities of the principal as the manager (Andriani et al., 2018; Khasanah et al., 2019; Renata et al., 2018; Salwa et al., 2019). The principal's function is not only as a manager, but also as a thinker and developer (brain power) whose main task is to think about the progress of the school. The principal is demanded to be able to act as a professional leader. The hallmark of professional school principals is mastering their work well beyond the average of other personnel at school, and having high moral commitment to their work relevant with the code of ethics of their profession (Kristiawan et al., 2019; Suparno, 2009).

Good teaching-learning process is inseparable from the role of a teacher who is able to guide, foster and makes students' excellent. The teacher is one component in teaching and learning activities and has a position that greatly determines the success of learning, because the main function of the teacher is to design, manage, implement and evaluate learning. Besides that, the position of the teacher in the learning process is also very strategic and decisive. Strategic because the teacher will determine the depth and breadth of the subject matter, while it is decisive because the teacher is sorting and choosing the subject matter to be presented (Zahroh, 2015).

The teacher is a professional whose position requires special expertise. The task of the teacher includes educating, teaching and training. Educating means developing life values, teaching means continuing and developing science and technology, while training means developing students' skills (Bukman Lian, 2018; Kurniasih, 2017). The teacher is an educator whose main task is teaching, in the sense of developing the realm of creativity, taste and intention of students as the ideal concept of educating implementation. Teacher's personality characteristics include cognitive flexibility, and psychological openness.

In accordance with the Law of the Republic of Indonesia No. 20 of 2003, concerning the National Education System, the position of teacher as an educator is a professional position. For this reason, teacher's professionalism is demanded to develop skill in accordance with the changing times, science and technology, as well as community needs including the need for quality human resources and capability to compete in regional, national and international forums (Sani, 2017).

The learning process is to develop existing activities into better activities, so that the educational goals that have been set are achieved well through a learning activity carried out by the teacher in accordance with the targets and objectives. Furthermore stated that teacher's performance is implementing the learning process both carried out in the classroom and outside the classroom in 
addition to working on other activities, such as working on school administration and learning administration, carrying out guidance and services to students, and carrying out assessments (Mangkunegara, 2011).

Performance appraisal is considered more effective when it is objective, uses appropriate techniques, actively engages employees, well understood, and accepted management responsibility. Ideally, performance evaluations are based on documented performance that is measured throughout the evaluation period for each of the established standards, but studies showed that performance evaluation is usually very subjective, even though formal systems are used. Appraisers may not have all the relevant facts regarding work conditions, actual qualities of individual behavior, and relative standards between assessments (Zahroh, 2015).

This paper determined whether there was positive influence of principal's supervision on the primary school's performance; school committee participation on the primary school's performance; and principal's supervision and school committee participation together on the primary school's performance in Pulau Rimau, Indonesia. Where the previous research (Khasanah et al., 2019; Renata et al., 2018) found that the principal's supervision could improve teacher's professionalism and motivation and impact to school's performance. The school committee has also the role and function as 1) advisory agency in determining and implementing educational policies in the educational unit; 2) supporting agencies in the form of financial, thought and energy in the administration of educational unit; 3) controlling the framework of transparency and accountability in the delivery of educational output in the educational unit; 4) mediator between the government and the community in the educational unit (Ministry of Education Number 10 of 2010). The influence of community participation to the school performance also showed by (Hadiyanto et al., 2017) espacially to the implementation of school based management.

We hope that teachers will be able to compete and work professionally. Teacher's competence is the ability and authority of teachers in carrying out their profession, while professionalism means the special qualities and behaviors that characterize professional teachers. Teachers are also expected to be able to carry out reciprocal activity between teachers and students in instructional situations. In this situation the teacher teaches and students learn (Zahroh, 2015).

In carrying out their duties, the teacher is not in an empty environment. It is part of a "big machine" of national education, and because of that it is bound to nationally established guidelines for what it must do. It is normal everywhere, but in the context of teacher's professionalism where teaching is considered a professional job the teacher is required to be professional in carrying out his duties (Sani, 2017). According to Mangkunegara, teacher's performance is a learning process to develop existing activities into better activities, so that educational goals that have been set are achieved well through a learning activity carried out by teachers in accordance with the targets and objectives (Mangkunegara, 2011). Furthermore, teacher's performance is implementing the learning process both carried out in the classroom and outside the classroom in addition to working on other activities, such as working on school administration and learning administration, carrying out guidance and services to students, and carrying out assessments (Rusyan, 2016).

\section{METHODS}

This research is quantitative survey which described the influence of principal's supervision and the school committee participation on the primary schools performance in Pulau Rimau, Indonesia. In this study, we are not required to provide treatment of the independent variables, but examine the facts that have been done by research subjects, and then measure the effects of these independent variables on certain dependent variables.

The population of this study is the teachers with the status of civil servants in SD Negeri Pulau Rimau in 2019, Banyuasin consist of 40 teachers. This research was conducted using questionnaires. Questionnaire was given to respondents in the form of questions that must be answered by the teacher. The questionnaire given was questions 
about the school principal's supervision and school committee participation on the primary schools performance. The teacher in this case assesses the school principal's supervision and the school committee participation in managing his school.

Questionnaires are distributed to each teacher as sampled in this study, in SD Negeri 2 Pulau Rimau were 15 teachers, SD Negeri 3 Pulau Rimau were 13 teachers, and SD Negeri 6 Pulau Rimau were 12 teachers. There were 40 teachers sampled in this study. To find out each item we analyzed using the SPSS Version 21. Before the instrument was conducted, calibration was first performed, testing the instrument to find out whether the instrument was suitable for research.

\section{FINDING AND DISCUSSIONS}

Based on the information of supervisor claster in Pulau Rimau, it was found that the obstacle was there many teachers who did not understand the importance of teaching programs such as lesson plans and so on, especially now all schools are demanded to use the curriculum 2013. In Banyuasin, particularly in rayon 2, there are 19 (nineteen) Public Primary Schools scattered in several villages. While from the principal of the school itself, through the supervision, he gave certainly quite positive influence on the primary school performance, because the pros and cons of an educational institution depend on the attitude of the school leadership.

Based on the above opinion, we used simple random sampling technique. Simple random sampling is taking sample members from population done randomly without regard to strata that exist in that population. In summary the sample sizes are presented in Table 1 below.

Table 1. Research Samples

\begin{tabular}{cllc}
\hline No. & SDN Name & Address & $\begin{array}{c}\text { Amount } \\
\text { Sampel }\end{array}$ \\
\hline 1 & $\begin{array}{l}\text { SDN 2 Pulau } \\
\text { Rimau }\end{array}$ & $\begin{array}{l}\text { Desa Dana } \\
\text { Mulia }\end{array}$ & 15 \\
2 & $\begin{array}{l}\text { SDN 3 Pulau } \\
\text { Rimau }\end{array}$ & $\begin{array}{l}\text { Desa } \\
\text { Nunggal } \\
\text { Sari } \\
\text { Desa } \\
3\end{array}$ & 13 \\
& $\begin{array}{l}\text { SDN 6 Pulau } \\
\text { Rimau }\end{array}$ & $\begin{array}{l}\text { Sumber } \\
\text { Rejeki }\end{array}$ & 12 \\
\hline & Total & $\mathbf{4 0}$ \\
\hline
\end{tabular}

Some of the obstacles faced by primary schools in Pulau Rimau more about the school principal's supervision and school committee participation so that the performance of primary schools on Pulau Rimau is even better. School Performance in Indonesia using the School-Based Quality Improvement Management model arises for several reasons as revealed by (Nurkholis, 2006) first, schools are more aware of their strengths, weaknesses, opportunities and threats, then schools can optimize the utilization of resources available to advance his school. Second, schools know more about their needs. Third, the involvement of school members and the community in decision making can create transparency and healthy democracy. The main step to change the school culture is to empower the principal as a leader and manager. During this time the duties and responsibilities of the principal as a leader and manager are very small. Principals tend to allocate their time to do school administration activities rather than other activities such as supervision of employees. In the era of improving the quality of education, principals must be equipped with leadership abilities, especially in improving the quality of education in order to realize the performance of competing schools.

Without the school committee participation, the quality of education certainly will not run well, because the active role of the school committee participation will have a positive impact on improving the school's performance, so that the government's goal to advance the nation through education in primary schools can be a milestone in Indonesia, the schools in our country can compete with other countries. Analysis of the results using the SPSS Version 21 as follows.

Table 2. Research Samples

\begin{tabular}{|c|c|c|c|c|}
\hline \multicolumn{5}{|c|}{ One-Sample Kolmogorov-Smirnov Test } \\
\hline & & $\begin{array}{c}\text { School } \\
\text { Principal's } \\
\text { Supervision }\end{array}$ & $\begin{array}{c}\text { School } \\
\text { Committee } \\
\text { Participation }\end{array}$ & $\begin{array}{c}\text { School's } \\
\text { Performance }\end{array}$ \\
\hline $\mathrm{N}$ & & 40 & 40 & 40 \\
\hline \multirow[b]{2}{*}{ Normal Parameters ${ }^{\mathrm{a}, \mathrm{b}}$} & Mean & 3.2463 & 2.3175 & 2.7740 \\
\hline & $\begin{array}{l}\text { Std. } \\
\text { Deviation }\end{array}$ & .31555 & .37716 & .27062 \\
\hline \multirow{3}{*}{ Most Extreme Differences } & Absolute & .098 & .197 & .104 \\
\hline & Positive & .092 & .197 & .058 \\
\hline & Negative & -.098 & -.090 & -.104 \\
\hline Kolmogorov-Smirnov Z & & .617 & 1.248 & .658 \\
\hline Asymp. Sig. (2-tailed) & & .841 & .089 & .779 \\
\hline \multicolumn{5}{|l|}{ a. Test distribution is Normal. } \\
\hline Calculated from data. & & & & \\
\hline
\end{tabular}


Table 3. Linearity Test Primary School Performance * School Principal's Supervision

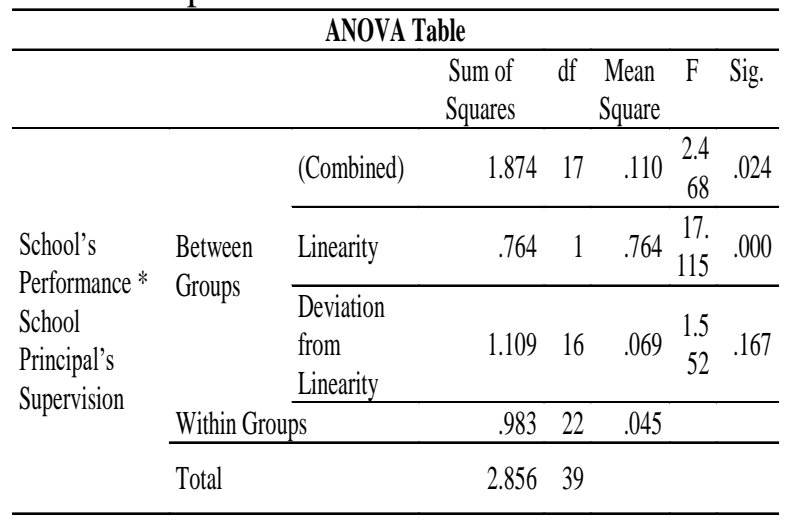

Table 4. Primary School Performance * School Committee Participation

\begin{tabular}{|c|c|c|c|c|c|c|c|}
\hline \multicolumn{8}{|c|}{ ANOVA Table } \\
\hline & & & $\begin{array}{l}\text { Sum of } \\
\text { Squares }\end{array}$ & $\mathrm{df}$ & $\begin{array}{c}\text { Mean } \\
\text { Square }\end{array}$ & $\mathrm{F}$ & Sig. \\
\hline \multirow{5}{*}{$\begin{array}{l}\text { School's } \\
\text { Performanc } \\
\text { e * School } \\
\text { Committee } \\
\text { Participatio } \\
\text { n }\end{array}$} & \multirow{3}{*}{$\begin{array}{l}\text { Between } \\
\text { Groups }\end{array}$} & (Combined) & 1.515 & 19 & .080 & $\begin{array}{r}1.18 \\
9\end{array}$ & .351 \\
\hline & & Linearity & .725 & 1 & .725 & $\begin{array}{r}10.8 \\
19 \\
\end{array}$ & .004 \\
\hline & & $\begin{array}{l}\text { Deviation } \\
\text { from } \\
\text { Linearity } \\
\end{array}$ & .790 & 18 & .044 & .654 & .815 \\
\hline & \multicolumn{2}{|c|}{ Within Groups } & 1.341 & 20 & .067 & & \\
\hline & Total & & 2.856 & 39 & & & \\
\hline
\end{tabular}

Table 5. Regression

\begin{tabular}{|c|c|c|c|c|c|c|}
\hline \multicolumn{6}{|c|}{ Modelsummali" } & \\
\hline Model & $R$ & \multicolumn{4}{|c|}{ RSquare Adjusted RSquare Std. Eiron of the Estimate } & \\
\hline 1 & $.609^{2}$ & .371 & 337 & & .20031 & \\
\hline \multicolumn{7}{|c|}{ a. Predictors: (Constan), School Committee Participation, School Principal's Supervision } \\
\hline \multicolumn{6}{|c|}{ 6. Dependent Variable' School's Performance } & \\
\hline \multicolumn{7}{|c|}{ ANOVA $^{\mathrm{a}}$} \\
\hline Model & & Sum of & Squares & & $\begin{array}{c}\text { Mean } \\
\text { Square }\end{array}$ & Sig. \\
\hline \multirow{3}{*}{1} & Regression & & 1.060 & 2 & .530 & $10.924 \quad .000^{\mathrm{b}}$ \\
\hline & Residual & & 1.796 & 37 & .049 & \\
\hline & Total & & 2.856 & 39 & & \\
\hline \multicolumn{7}{|c|}{ a. Dependent Variable: School's Performance } \\
\hline \multicolumn{7}{|c|}{$\begin{array}{l}\text { b. Predictors: (Constant), School Principal's Supervision, School Committee } \\
\text { Participation }\end{array}$} \\
\hline
\end{tabular}

\begin{tabular}{|c|c|c|c|c|c|c|}
\hline \multirow{3}{*}{\multicolumn{2}{|c|}{$\overline{\text { Model }}$}} & \multicolumn{3}{|c|}{ Coefficients $^{\mathrm{a}}$} & \multirow{3}{*}{$t$} & \multirow{3}{*}{ Sig. } \\
\hline & & \multicolumn{2}{|c|}{ Coefficients } & Standardized & & \\
\hline & & B & $\begin{array}{l}\text { Std. } \\
\text { Error }\end{array}$ & Beta & & \\
\hline & (Constant) & 1.146 & .372 & & 3.076 & .004 \\
\hline 1 & $\begin{array}{l}\text { School Principal's } \\
\text { Supervision }\end{array}$ & .321 & .122 & .375 & 2.627 & .012 \\
\hline & $\begin{array}{l}\text { School Committee } \\
\text { Participation }\end{array}$ & .253 & .102 & .352 & 2.469 & .018 \\
\hline
\end{tabular}

Based on the findings, it is stated that there was an effect of the school principal's supervision and the participation of the school committee together on school's performance in Pulau Rimau. This can be seen from the analysis results obtained that the value > r-table. In other words, the calculated value $>0.312$ for the $5 \%$ confidence level and 0.403 for the $1 \%$ confidence level. To improve the performance of educational quality in schools is done through the school principal's supervision in collaboration with school committee participation seen as an effective alternative to improve the quality of education as well as the quality of human resources. School performance will go well according to what is expected and very useful for developing this country. It is undeniable that every parent wants their child to become a superior human being. This can be seen from the interest of the community to enroll their children in leading schools. Every new school year, the Accredited A schools are crowded with prospective students, because of the belief that they can produce superior humans.

The principal as a leader must also have these qualities. Principals as leaders are people who are able to influence the behavior of school personnel so they are willing to work together to achieve educational goals at school. Principal's leadership is the principal's effort to influence, encourage, guide, direct and move teachers, staff, students, parents and other individuals involved to work together in achieving the goals set. The principal's role as a leader is mainly emphasized on how the principal is able to make other people work in order to achieve the goals set by the school.

A good school principal should have good leadership characteristics and behavior and can provide balanced compensation to teachers so that it creates motivation to excel among them. Principals should have a clear 
vision of institutional conceptual abilities, and have skills and arts in the relationship between humans, mastering technical and substantive aspects, have a passion for progress and a spirit of service and character that is accepted by the community (Mulyasa, 2004).

Principal's leadership pattern will be very influential even very determine the progress of the school. The principal as a leader must be able to motivate his subordinates, because the success of a leader in moving people to achieve goal is very dependent on the authority they have. The new management paradigm of education gives broad authority to principals in planning, organizing, implementing, supervising and controlling education in schools. (Mulyasa, 2004) said that professional school principals in the new paradigm of educational management will have a positive impact and a fairly fundamental change in the renewal of the educational system in schools.

The learning process carried out in schools is inseparable from the participation of the school committee, to get better education in schools always involves the participation of the school committee and is not separated from the leadership of the school principal. Thus, leadership through the principal supervision and good school committee participation will realize the success of primary school's performance.

The description above means that the principal's supervision is very important in determining the success or failure of the school in carrying out its duties as a school leader to educate the national life and develop the whole person (Khasanah et al., 2019; Murtiningsih et al., 2019; Renata et al., 2018; Salwa et al., 2019). Good or bad a school is more determined by the professional abilities of the principal as the manager. The principal's function is not only as a manager, but also as a thinker and developer (brain power) whose main task is to think about the progress of the school. The principal is demanded to be able to act as a professional leader (Andriani et al., 2018; Apriana et al., 2019; Irmayani et al., 2018). The hallmark of professional school principals is mastering their work well beyond the average of other personnel at school, and having a high moral commitment to their work in accordance with the code ethics of their profession (Suparno, 2009).

After school experiences difficulties in dealing with students' educational problems caused by differences in parents' socio-cultural, ethnic or economic backgrounds, it is realized that there is a need for a relationship with each other to discuss this. The school committee participation led to accommodate the aspirations of both parties. The relationship between schools and parents and the community reaches a good level of cooperation in order to create primary school's performance can be used as a reference for students to continue their education to secondary school.

\section{CONCLUSION}

Based on the research findings it can be concluded that there was positive influence of principal's supervision and school committee participation on the primary school's performance. To improve the performance of educational quality in schools is done through the school principal's supervision in collaboration with school committee participation seen as an effective alternative to improve the quality of education as well as the quality of human resources. This paper contributed to improve principal's supervision and committee's participation where the school will have very good performance. The principal's supervision and school committee participation should help teachers improve teaching problems. It could be implemented through group discussions, class visits, individual talks, and learning simulations.

\section{ACKNOWLEDGMENT}

We would like to express our special thanks and gratitude to Rector Universitas PGRI Palembang, Director of Graduate Program Universitas PGRI Palembang, and Dean of Faculty Education Universitas Bengkulu who gave us the support to do this wonderful project. This project was funded independent. Secondly, we would also like to thank our friends and teachers in Graduate Program of Educational Management and SD Negeri 3 Pulau Rimau who helped us a lot in finalizing this project within the limited time frame. 


\section{REFERENSI}

Andriani, S., Kesumawati, N., \& Kristiawan, M. (2018). The influence of the transformational leadership and work motivation on teachers performance. International Journal of Scientific and Technology Research, 7(7), 19-29.

Apriana, D., Kristiawan, M., \& Wardiah, D. (2019). Headmaster's competency in preparing vocational school students for entrepreneurship. International Journal of Scientific and Technology Research, 8(8), 1316-1330.

B, S. (2017). Kompetensi Pedagogik, Teori dan Praktik Untuk Peningkatan Kinerja dan Kualitas Guru (Pedagogical Competence, Theory and Practice for Improving Teacher Performance and Quality). Kata Pena.

Bukman Lian, M. K. (2018). Giving Creativity Room to Students through the Friendly School's Program. International Journal of Scientific \& Technology Research, 7(7).

Hadiyanto, Suryadi, Y. S., \& Zulaikha, S. (2017). Autonomy And Community Participation On The Implementation Of School-Based Management In The City Of South Tangerang. 118, 1126-1131. https://doi.org/10.2991/icset-17.2017.183

Irmayani, H., Wardiah, D., \& Kristiawan., M. (2018). The strategy of SD Pusri in Improving educational quality. International Journal of Scientific and Technology Research, 7(7), 113-121.

Irwan Fathurrochman, Budiman, D. A., Alamsyahril, \& Kristiawan, M. (2019). Revitalization Management of Islamic Boarding School Preventing the Radicalism. Restaurant Business, 118(10), 495-505. https://doi.org/10.26643/rb.v118i10.9462

Khasanah, U., Kristiawan, M., \& Tobari. (2019). The Implementation of principals' Academic Supervision in Improving Teachers' Professionalism in the State Primary Schools. International Journal of Scientific and Technology Research, 8(8), 1107-1115.

Kristiawan, M., Nizarani, \& Syamsidar. (2019). Role of school on forming character of z-generation through entrepreneurial skills. International Journal of Scientific and Technology Research, 8(10), 1941-1945.

Kurniasih, I. (2017). Kompetensi Pedagogik, Teori dan Praktik Untuk Peningkatan Kinerja dan Kualitas Guru (Pedagogical Competence, Theory and Practice for Improving Teacher Performance and Quality). Kata Pena.

Mangkunegara, A. P. (2011). Manjemen Sumber Daya Manusia Perusahaan. PT. Remaja Rosda Karya.

Mulyasa. (2004). Menjadi Kepala Sekolah Profesional [Become a Professional Principal]. ROSDA.

Murtiningsih, Kristiawan, M., \& Lian, B. (2019). The Correlation Between Supervision of Headmaster and Interpersonal Communication With Work Ethos of the Teacher. European Journal of Education Studies, 6(1), 246-256. https://doi.org/10.5281/zenodo.2649535

Nurkholis. (2006). Manajemen Berbasis Sekolah Teori, Model, dan Aplikasi (School Based Management Theories, Models, and Applications). Grasindo.

Renata, Wardiah, D., \& Kristiawan, M. (2018). The influence of headmaster's supervision and achievement motivation on effective teachers. International Journal of Scientific and Technology Research, 7(6), 44-49.

Rusyan. (2016). Manajemen Peningkatan Kinerja Guru. Konsep Strategi dan Implementasi (Teacher Performance Improvement Management. Strategy and Implementation Concepts). Remaja Rosdakarya.

Salwa, Kristiawan, M., \& Lian, B. (2019). The Effect of Academic Qualification, Work Experience and Work Motivation Towards Primary School Principal Performance. International Journal of Scientific and Technology Research, 8(8), 969-980.

Sarina, Kristiawan, M., \& Wardiah, D. (2019). Module development the utilization of patchwork fabric as teaching materials crafts on the subjects of craft and entrepreneurship for high school students. International Journal of Scientific and Technology Research, 8(5), 124-130. 
Suparno. (2009). Manajemen Berbasis Sekolah: Konsep, Strategi, dan Implementasi (School Based Management: Concepts, Strategies and Implementation). Remaja Rosdakarya.

Tobari, Kristiawan, M., \& Asvio, N. (2018). The Strategy of Headmaster on Upgrading Educational Quality in Asean Economic Community (AEC) era. International Journal of Scientific and Technology Research, 7(4), 72-79.

Wandasari, Y., Kristiawan, M., \& Arafat, Y.
(2019). Policy evaluation of school's literacy movement on improving discipline of state high school students. International Journal of Scientific and Technology Research, 8(4), 190-198.

Zahroh, A. (2015). Membangun Kualitas Pembelajaran Melalui Dimensi Profesionalisme Guru (Building Quality Learning Through the Dimensions of Teacher Professionalism). Yrama Widya. 